\title{
Ernæring til kreftsyke barn
}

Kreftpasienter blir lett underernærte, noe som gir dårligere prognose. Derfor bør man legge inn gastrostomi til de fleste barn med kreft.

\section{Forfattere}

\section{Jostein Kristoffer Stemland}

Barne- og kreftsykepleier

Nordlandssykehuset, Bod $\varnothing$

\section{Nøkkelord}

\section{Kreft Barn Ernæring}

Sykepleien 2017 105(4)(66-69)

DOI: https://doi.org/10.4220/Sykepleiens.2017.61269

\section{HOVEDBUDSKAP}

Ernæring til barn med kreft kan være en utfordring. Kanskje kan innleggelse av gastrostomi tidlig i sykdomsforløpet forbedre barnets ernæringsstatus og overlevelse.

Da jeg i 2016 ble far for første gang, ble det veldig konkret for meg hvor viktig ernæringen faktisk er for oss mennesker. Ernæring er et grunnleggende behov (1), og jeg anser maten som selve fundamentet i livet til det nyfødte barnet. Selv om barnet stadig tilegner seg nye ferdigheter, er maten fortsatt like viktig. Jeg synes derfor det er rart at det ikke har vært mer oppmerksomhet på ernæring i grunn- og videreutdanningen i sykepleie. 


\section{Sykepleieteoretikere}

Florence Nightingale uttalte at sykepleiere fokuserer for lite på ernæring. Selv om vi har overflod av mat, sulter tusenvis av pasienter årlig fordi helsepersonell vier for lite oppmerksomhet til hver enkelt pasients ernæringsbehov. Konsekvensen blir at pasientens ernæringsstatus ikke blir ivaretatt (2). Selv om Nightingale døde for over 100 år siden, oppfatter jeg uttalelsene hennes som like aktuelle i dag.

Virginia Henderson mente at uavhengig av om mennesket er friskt eller sykt, bør sykepleieren være oppmerksom på grunnleggende behov, slik som ernæring. Det er trolig ikke noe fag i sykepleierutdanningen som er viktigere enn ernæringslære. Selv om det finnes ernæringsfysiologer på sykehuset som kan lage ernæringsplaner, er det likevel sykepleieren som er tettest på pasienten under oppholdet på sykehuset. Sykepleieren har derfor den beste muligheten til å oppmuntre pasienten til å spise samt observere og rapportere hva pasienten liker, ikke liker eller ikke tåler (1).

\section{Ernæring til barn}

Barn er avhengige av jevn tilførsel av energi og næringsstoffer for å utvikle seg og vokse, og derfor er det viktig med hyppige måltider. Energibehovet til barn er faktisk større enn energibehov per kilo kroppsvekt for voksne, og det gjør dem sårbare for ernæringssvikt ved sykdom. Faktorer som påvirker energibehovet er vekstperiode, aktivitetsnivå og sykdomstilstand (3). 
Den enkleste måten å sjekke om barnet spiser tilstrekkelig, er daglig vektkontroll. Fra sykehuset bør de derfor anbefale daglig vektkontroll av barnet til fast tidspunkt. Resultatene føres inn i kurve, og percentilskjema fylles ut etter alder (4-6).

Vektnedgang hos et barn får raskere negative konsekvenser enn hos voksne (5). Barn som er underernærte, blir ofte dårlig behandlet eller ikke fulgt opp. Gode rutiner for vektkontroll og oppfølging av vekttap gjør at man tidlig kan iverksette tiltak (6-8).

\section{Kreftsyke barn}

Alle barn med kreft er i utgangspunktet i faresonen for å utvikle feil- eller underernæring, noe de ofte gjør (9, 10). Feil- eller underernæring kan skyldes nedsatt appetitt som følge av cytostatika, såre slimhinner, steroidbehandling, nedsatt allmenntilstand og perioder med infeksjoner. Skal man forebygge underernæring, bør man komme tidlig i gang med tiltak $(10,11)$.

\section{三 «Barn med god ernæringsstatus tåler behandlingen bedre.»}

Barn med god ernæringsstatus tåler behandlingen bedre. Immunforsvaret er bedre rustet, beinmargsdepresjon etter kur blir kortere, og det blir ofte færre utsettelser i behandlingsforløpet (6). I tillegg er god ernæringsstatus viktig for å opprettholde samme normale vekst og utvikling som hos jevnaldrende (12). God ernæringsstatus bedrer også prognosene for overlevelse (13). Ved vekttap over tid kan det være aktuelt å gi sondeernæring (5).

Kroppsmasseindeks (KMI) er et verktøy som kan brukes for å definere over- og undervekt. Min erfaring er imidlertid at KMI er et dårlig verktøy for å måle ernæringsstatus hos barn, ettersom de er i konstant vekst og utvikling. Det er viktig med individuelle vurderinger av behovet for energi og næringsstoffer hos barn. For barn med kreft er ernæring en støtte til selve kreftbehandlingen (3). 
Hvis foreldrene mangler oversikt og kunnskap om ernæringssituasjonen, kan de sette i gang et vedvarende mas overfor barnet, som hemmer barnets inntak (10). Tidlig informasjon om ernæring samt oppmerksomhet på ernæringsstatus, energiinntak og energiforbruk er viktig for å unngå underernæring (14).

Som barne- og kreftsykepleier har jeg derfor en komplisert og veldig viktig oppgave med å følge gjeldende protokoller samtidig som jeg skal ivareta barnets grunnleggende behov gjennom hele forløpet. Det kan settes opp ernæringsplaner og gjøres andre tiltak, men det er jeg som er tettest på pasienten, og mine observasjoner og tiltak er viktige for å gjennomføre behandlingen (1).

\section{Peroral ernæring}

Så lenge barnet har en fungerende mage-tarm-kanal, bør man forsøke å opprettholde enteral ernæring. Hvis barnet klarer å spise, men ikke spiser tilstrekkelig, kan det være aktuelt å berike den maten som barnet spiser, eller gi næringsdrikke i etterkant av måltidet (3).

Min erfaring fra praksis er imidlertid at dette sjelden gjennomføres i tilstrekkelig grad. Hvis barnet får utarbeidet en kostplan i samarbeid med klinisk ernæringsfysiolog, følges denne gjerne slavisk. Da dokumenterer de om det som er satt opp på planen, er spist eller ikke spist. Har ikke barnet fått utarbeidet en slik plan, opplever jeg at det er lite system i å dokumentere hva barnet skal ha av mat, og av hva som blir gitt. 
Beriking og tilskudd med næringsdrikke blir gitt ut fra kunnskapen og erfaringene til den sykepleieren som er på jobb, og dermed blir det ikke et helhetlig tilbud. Det beste er selvsagt at barnet får utarbeidet en ernæringsplan. Ettersom denne planen ofte følges slavisk, opplever jeg imidlertid at barnet kan gå lei av maten. Jeg mener at man som kreftsykepleier bør kunne tenke selv og være litt kreativ med maten, slik at dagene ikke flyter over i hverandre med samme mat hver dag.

\section{ERN/ERINGSMÅTER}

Peroral ernæring: Ernæring som inntas gjennom munnen.

Enteral ernæring: Ernæring som blir gitt i mage-tarmkanalen via sonde. I hovedsak dreier det seg om flytende, industrielt fremstilte ernærings|øsninger.

Parenteral ernæring: Tilførsel av næring eller væske ved injeksjon eller infusjon.

Kilde: Store medisinske leksikon

\section{Sondeernæring}

I behandlingen av barnekreft er det påvist at dårlig ernærte barn har dårligere prognose. Likevel blir ernæringen fortsatt ofte oversett (15). Spiser ikke barnet tilstrekkelig selv, kan man ta i bruk sondeernæring som gis via nasogastrisk sonde lagt gjennom nesen. Barnet kan også få innlagt en gastrostomi rett inn i magesekken (10).

\section{«Sondeernæring er en sikker og effektiv måte å gi ernæringsstøtte på.»}


Sondeernæring fortrekkes fremfor parenteral ernæring fordi den hindrer tarmatrofi og infeksjon (5). Sondeernæring er en sikker og effektiv måte å gi ernæringsstøtte på. Den bør gis tidlig i forløpet for å forebygge underernæring fordi det er påvist at vekttapet er størst i starten av forløpet. Avgjørelsen vedrørende bruk av sondeernæring til pasienter som trenger det, bør tas tidligere enn det gjøres i dag hvis slik ernæring skal ha optimal effekt (16).

Nasogastrisk sonde skal benyttes når behovet for sondeernæring er inntil fire til seks uker. For å dekke behov utover dette bør det etableres en gastrostomi (3). Min erfaring er imidlertid at kreftsyke barn ofte trenger ernæringsstøtte i store deler av behandlingen. Noen trenger det hver dag i hele forløpet, men variasjonene er selvfølgelig mange, og noen trenger det bare i de tøffeste periodene.

Man skal velge gastrostomi hvis behovet er vedvarende utover fire til seks uker $(3,17)$. Noen hevder at gastrostomi bør anlegges ved behov utover to til tre uker (17). Hva gjør man imidlertid med de barna som trenger sondeernæring én til fire uker annenhver måned? Etter definisjonen trenger de ikke gastrostomi, men kunne de likevel hatt behov for det? Når man trenger sondeernæring i flere korte perioder og man får lagt inn sonde gjennom nesen, må det legges ned ny sonde hver gang behovet oppstår.

\section{Ubehag ved sonde}

Det er en ubehagelig prosedyre å få lagt ned nasogastrisk sonde, og da spesielt for barn som har en tendens til å kaste opp eller rive ut sonden (10). Når sonden rives ut eller kastes opp i den perioden barnet trenger sondeernæring, må man legge den ned på nytt, og barnet påføres ekstra ubehag. Ved gjentatte sondenedleggelser opplever jeg at barnets humør påvirkes, og tilliten til meg som kreftsykepleier svekkes. I tillegg skaper sonden irritasjon i nese og svelg, og barnets utseende blir påvirket negativt (17). 
Innleggelse av gastrostomi gjør sonden mindre synlig, men det er et kirurgisk inngrep som kan medføre komplikasjoner. Alvorlige komplikasjoner er imidlertid sjeldne, og de fleste av komplikasjonene kan unngås om man er oppmerksom på riktig teknikk under innleggelsen (18). Gastrostomien vil være mindre synlig på barnet samtidig som det er enklere og mindre ubehagelig å skifte gastrostomi. Den kan ikke ligge inne mer enn to til tre måneder før man må ta ut den gamle og legge inn en ny (16).

\section{Gastrostomi i praksis}

Gastrostomi gjør det mulig å gi sondeernæring hele tiden, altså med én gang barnet trenger det. Barnet og foreldrene slipper å komme inn på sykehuset for å få lagt ned sonden først. De barna som har fått lagt inn en gastrostomi, har det bedre enn dem som går lenge med nesesonde. Familiene får bedre kommunikasjon og bedre trivsel under måltidene (17).

\section{三 «Dagens praksis for å anlegge gastrostomi er imidlertid ganske restriktiv.»}

Dagens praksis for å anlegge gastrostomi er imidlertid ganske restriktiv (10). Ifølge legene jeg har snakket med, innebærer det en stor infeksjonsrisiko å legge inn gastrostomi. Hvis barnet derimot ikke får inn tilstrekkelig med mat i mage-tarm-kanalen, gir det igjen fare for tarmatrofi og infeksjon (5).

Uansett type sonde blir det enklere å gi medisiner peroralt. Barna får mulighet til en bedre ernæringstilstand, som videre fører til nedsatt infeksjonsrisiko (10). Hvilken av de to løsningene man velger, avhenger ifølge teorien av hvor lenge pasienten har behov for sondeernæring (3). I praksis oppfatter jeg at det legges ned en nesesonde når man bestemmer seg for at det er behov for sondeernæring uten å vurdere før oppstart hvor lenge pasienten vil ha behov for sondeernæring (5). 


\section{Parenteral ernæring}

Parenteral ernæring (PN) er en mulighet hvis det ikke kan gis tilstrekkelig ernæring gjennom munnen eller sonde. I praksis opplever jeg ofte at kreftsyke barn må få denne typen tilførsel av ernæring. Årsaken er da ofte manglende inntak på egen hånd og vegring for nesesonde. Man må imidlertid være klar over at slik ernæring gir økt risiko for komplikasjoner, og at mangeltilstander raskt kan oppstå hvis man ikke tilsetter vitaminer og sporstoffer i løsningen.

Det er helt klart at PN er siste utvei for dem som har en fungerende mage-tarm-kanal (3). Min erfaring er at de pasientene som får PN, ofte må ta daglige blodprøver for at legen skal kunne gjøre sine doseringer for det kommende døgnet. Jeg har kun opplevd at kreftsyke barn i terminalfasen har fått reise hjem med mulighet for å administrere PN hjemme. De barna som trenger PN i behandlingsforløpet, blir innlagt på sykehuset, ofte i lengre perioder. Det kan medføre at de ikke kommer seg hjem mellom kurene.

\section{Bør få gastrostomi}

Litt enkelt sagt skal kreftsykepleieren hjelpe familien med å leve mest mulig normalt i en hverdag med medisiner og behandling som påvirker blant annet matlysten. Erfaringer både fra praksis har gjort meg bevisst på at man ikke kan tvinge et barn til å spise. Når munnen er lukket, har det sin årsak, og det er ikke noe man kan gjøre med det. Det kan skyldes at barnet vil noe annet eller ikke likte smaken etter første skje. 
De kreftsyke barna kan ha de samme grunnene til ikke å ville spise, men de kan også være rammet av bivirkninger som kvalme, tørre slimhinner, munntørrhet eller smaksforandringer. De kan også være plaget med at medisiner som må tas peroralt, har vond ettersmak. Disse bivirkningene gjør at barnet spiser mindre enn normalt. I tillegg kan de føre til at barnet kaster opp og dermed mister mer mat enn det får inn. Dette igjen kan føre til at barnet mister lysten på enkelte typer mat på grunn av lukt, smak, farge eller konsistens. Det kan med andre ord være ganske utfordrende å skulle ivareta ernæringen til et kreftsykt barn.

Jeg mener at man burde legge inn gastrostomi til de fleste barn som får kreft ettersom alle kreftpasienter potensielt blir underernærte (11) og fordi det er viktig å opprettholde enteral ernæring. Noen barn klarer seg uten sondeernæring gjennom behandlingsforløpet.

Derfor kunne man sett på hvilke diagnoser, aldersgrupper, behandlingsformer med mer som gir størst fare for ernæringsproblemer. De som får en kreftdiagnose og er i risikosonen, kunne fått lagt inn en gastrostomi samtidig som de fikk lagt inn sentralt venekateter. På den måten kan barnet få både nødvendig medisin og ernæring gjennom behandlingsforløpet.

\section{Kan være mer hjemme}

Jeg mener også at et barn som tidlig får anlagt en gastrostomi, kommer til å få det enklere gjennom behandlingsforløpet. Barnet kan spise det hun eller han vil og i den mengden barnet klarer. Maten kan gjerne være beriket, men gastrostomien er tilgjengelig slik at barnet får all næringen det har behov for. Medisiner og miksturer som barnet ikke orker innta via munnen, kan settes rett i gastrostomien. På den måten tror jeg at foreldrene kommer til å mase mindre på barna. Man kan i stedet ha mer oppmerksomhet på å gjøre noe positivt ut av alle dagene som må tilbringes på sykehus. 


\section{三 «Jeg mener at et barn som tidlig får anlagt en gastrostomi, kommer til å få det enklere gjennom behandlingsforløpet.»}

I perioder mellom kurer kan familien være mer hjemme når barnet har gastrostomi. Foreldrene kan gi maten som barnet ikke spiser selv, i gastrostomien. Mat bør etter min oppfatning være noe positivt og trivelig. Det tror jeg det fortsatt vil være om man tar i bruk de hjelpemidlene som finnes og bruker dem på riktig måte. Derfor bør bruk av parenteral ernæring være siste utvei, men et nødvendig tilskudd om barnet i perioder har mye oppkast eller annet ubehag som gjør det vanskelig med enteral ernæring.

\section{Ikke i mål}

I artikkelsøket til denne artikkelen fant jeg en 24 år gammel artikkel som tar for seg flere av de momentene som jeg har belyst her. På de 24 årene som har gått, oppfatter jeg at vi fortsatt ikke har kommet i mål med en optimal ernæringsbehandling, selv om vi vet at det er viktig for utfallet av kreftsykdommen.

Mye er opp til den sykepleieren som behandler pasienten, og avhenger av hvor mye vedkommende fokuserer på ernæring. Det er sykepleieren som er tettest på pasienten og dermed har størst mulighet til å påvirke. Som barne- og kreftsykepleier har jeg god mulighet til å utgjøre en forskjell, og jeg ønsker å være en pådriver for at behandlingen av kreftsyke barn gjennomføres med langsiktige løsninger som er til det beste for barnet. En av de løsningene er bedre ernæring, og trolig økt bruk av gastrostomi.

\section{Referanser}

1. Henderson V. ICN: Sykepleierens grunnprinsipper. Oslo: Norsk Sykepleierforbund, 1997. 
2. Nightingale F. Notater om sykepleie. Oslo:

Universitetsforlaget. 1997.

3. Helsedirektoratet. Kosthåndboken - Veileder i ernæringsarbeid i helse- og omsorgstjenesten. Oslo. 2015.

4. Henriksen C. Barn og ungdom. I: Drevon CA mfl. (red.). Mat og medisin. Oslo: Cappelen Damm Høyskoleforlaget. 2012, s 317-29.

5. Egeland S. Sykepleieutfordringer ved kreft hos barn. I: Reitan AM (red.). Kreftsykepleie. Oslo: Akribe forlag. 2014, s. 692-705.

6. Sjøen RJ, Thoresen L. Sykepleierens ernæringsbok. Oslo: Gyldendal Akademisk. 2008.

7. Iniesta RR, Paciarotti I, Brougham MFH, McKenzie JM, Wilson DC. Effects of pediatric cancer and its treatment on nutritional status: a systematic review. Nutrition Reviews 2015;5:276-95.

8. Varre P. Sykepleieutfordringer ved kjemoterapi. I: Reitan AM (red.). Kreftsykepleie. Oslo: Akribe forlag. 2014, s 161-73.

9. Ward EJ, Henry LM, Friend AJ, Wilkins S, Phillips RS. Nutritional support in children and young people with cancer undergoing chemotherapy. The Cochrane Library 2015 Aug 24;(8)1-115.

10. Bringager H, Hellebostad M, Sæter R, Mørk AC. Barn med kreft. Oslo: Gyldendal Norsk Forlag. 2014.

11. Bye A. Ernæring. I: Reitan AM (red.). Kreftsykepleie. Oslo: Akribe forlag. 2014, s. 692-705. 
12. Murphy AJ, White M, Elliott SA, Lockwood L, Hallahan A, Davies PSW. Body composition of children with cancer during treatment and in survivorship. The American Journal of Clinical Nutrition 2015;102:891-6.

13. Adler Y, Namedar RL. Perceptions of pediatric hematology physicians and nurses about gastrostomy. SIOP Abstracts, International Society of Paediatric Oncology October 21-24 2010; Boston.

14. Bauer J, Jürgens H, Frühwald MC. Important aspects of nutrition in children with cancer. American Society for Nutrition 2011;2:67-77.

15. Viani K, Bouchabki G, Nabarrete J, Oliveira V, Manzoli B, Neto Rafael M, Feferbaum R. Impact of the implementation of a nutrition therapy protocol on undernutrition in children and adolecents with cancer. Nutrition and Cancer 2015;34:7.

16. Löser C, Aschl G, Hébuterne X, MathusVliegen EMH, Muscaritoli M, Niv Y, Rollins H, Singer P, Skelly RH. ESPEN guidelines on artificial enteral nutrition-Percutaneous endoscopic gastrostomy (PEG). Clinical Nutrition 2005;24:848-61.

17. Åvitsland TL, Emblem R. Gastrostomi hos barn. Kirurgen 2013;2:97-9. 